\title{
Increase in the Number of Hot Days for Decades in Puerto Rico $1950-2014$
}

\author{
Rafael Méndez-Tejeda ${ }^{1}$ \\ ${ }^{1}$ Natural Science Department, Atmospherical Science Laboratory, University of Puerto Rico, Carolina Puerto \\ Rico, PO. Box 4800. Carolina P.R. 00966, USA \\ Correspondence: Rafael Méndez-Tejeda, Natural Science Department, Atmospherical Science Laboratory, \\ University of Puerto Rico, Carolina Puerto Rico, PO. Box 4800. Carolina P.R. 00966, USA. E-mail: \\ rafael.mendez@upr.edu
}

Received: May 17, 2017

Accepted: May 27, 2017

Online Published: July 6, 2017

doi:10.5539/enrr.v7n3p16

URL: https://doi.org/10.5539/enrr.v7n3p16

\begin{abstract}
The results show that the number of days with temperatures higher than $32{ }^{\circ} \mathrm{C}$ has increased, and the number of days with a minimum temperature of $15{ }^{\circ} \mathrm{C}$ has decreased. The average temperature on the island has increased by $2.24^{\circ} \mathrm{C}$ in the period analyzed. The increase in the minimum temperature is more than two times greater than the increase in the maximum temperature in the analyzed period. The number of days with temperatures over $32^{\circ}$ $\mathrm{C}$ is three times more than the number of days with temperatures below $15^{\circ} \mathrm{C}$.

When analyzing the behavior per decade it is found that there is an increase in the ratio between cold and warm days, from the 1950s, which was from 1: 1.79 to that of 2000-2019, which is 1:3.28.
\end{abstract}

Keywords: Temperature variability, climate change, Caribbean, Puerto Rico

\section{Introduction}

Several researchers have found that the projected changes in global climate have caused serious negative consequences for the Caribbean as a whole. It is becoming increasingly evident that the impacts of climate change will not be felt uniformly throughout the region (PRCC, 2014, Strelich, 2015; Nurse et al., 2014; Taylor et al., 2012). Their findings reported that the climate of the Caribbean region is changing and that the range of intra-annual extreme temperatures is decreasing. According to the National Climate Assessment, average annual air temperatures in the Caribbean islands increased by more than $0.6{ }^{\circ} \mathrm{C}$ in the last century.

In the United States (Meehl et al., 2009), reports an analysis of the annual ratio of US record daily maximum to record daily minimum temperatures, showing that recent values of about 2 to 1 are just transients, and that the ratio is increasing with average annual mean over the US in the period from 1950 to 2000.

Observational records for the Caribbean beginning as early as the late 1950s have shown that the number of very hot days (Tmax greater than or equal to $30^{\circ} \mathrm{C}$ ) and very hot nights (Tmin greater than or equal to $25^{\circ} \mathrm{C}$ ) have been increasing throughout the region (Rhiney, 2015, Peterson et al., 2002; Stephenson et al., 2014). Studies have also shown that the Caribbean Sea has warmed by approximately $1.5^{\circ} \mathrm{C}$ over the last century and that sea surface levels have risen in line with that of the global mean $(\sim 1.8 \mathrm{~mm} / \mathrm{yr})$ since 1950 (Palanisamy, 2012).

The number of very hot days and nights is increasing drastically, while the numbers of cool days and nights are declining. An analysis carried out by (Méndez-Lázaro, 2016) establishes a relation between the increase of the episodes of heat and with health problems. The main finding of the paper is the increase in the significant effect of high temperatures on mortality for the summers of 2012 and 2013.

Added to these trends is a moderate decline in precipitation across the northern Caribbean basin, coupled with evidence of greater seasonal and inter-annual rainfall variability and increasingly frequent and prolonged dry spells, especially during the summer (Gamble, 2009). The latter trend is particularly important, given the fact that the Caribbean's climate regime has traditionally been characterized by dry winter months and wet summer months (Chen \& Taylor, 2002; Méndez-Lázaro, 2015).

The model for the Special Report on Emissions Scenarios (SRES IPCC) A2 and B2 projects a one to five ${ }^{\circ} \mathrm{C}$ increase in annual mean temperature for the Caribbean by the 2080s, compared to the 1960-1990 baseline 
(Climate Change, 2014). This warming will be greater in the northwest sub-region (Jamaica, Cuba, Hispaniola, and Belize) in comparison to the eastern Caribbean island chain, and greater in the summer months than in the drier early months of the year. These results compare favorably with other regional modeling studies. For example, the study by Hall et al. (Hall et al., 2013) has also predicted a general increase in the mean surface temperature across the entire Caribbean basin by the end of the century $\left(2-3{ }^{\circ} \mathrm{C}\right.$, scenario A1B), but with slightly greater warming projected for the northern Caribbean $\left(2.5-3{ }^{\circ} \mathrm{C}\right)$ compared to the eastern and southern Caribbean sub-regions $(2-$ $\left.2.5^{\circ} \mathrm{C}\right)$.

Several authors such as (Foltz \& McPhaden, 2007; Chunzai, 2011) suggest that the Sahara dust exerts a great influence on the Sea surface temperature (SST) of the tropical North, which plays an important role in increasing the temperatures in this region. Lau and Kim (2007) based on estimates of Sea Surface Temperature (SST) cooling due to solar attenuation by Saharan dust, and analyses of correlations from historical data, we have provided preliminary evidences supporting the notion that solar attenuation effects due to increased (decreased) Saharan dust loading over the Atlantic may contribute to widespread cooling (warming) of the underlying sea surface in the early hurricane season.

Table 1. Shows the selection of some papers that have reported temperature trends in the Caribbean

\begin{tabular}{|c|c|c|c|}
\hline Article & Period & Method & Remarks \\
\hline Duchon 1986 & 28 years $(1958-1983)$ & $\begin{array}{l}\text { Surface Temperature } \\
\text { Data from NOAA }\end{array}$ & $\begin{array}{c}\text { San Juan, Puerto Rico, International } \\
\text { aeropuerto } 2.1^{\circ} \mathrm{C} \text {. }\end{array}$ \\
\hline Singh 1997 & 5 -year & $\begin{array}{c}\text { 5-year equilibrium runs of the Canadian } \\
\text { Climate Centre (CCC) general circulation } \\
\text { model (GCM) }\end{array}$ & $\begin{array}{l}\text { An increase in the average temperature } \\
1.5^{\circ} \mathrm{C} \text {, while in Rizet (Guadaloupe) the } \\
\text { increase is } 1.3^{\circ} \mathrm{C} \text {, however in San Juan, } \\
\text { Puerto Rico is }\left(2.3^{\circ} \mathrm{C}\right) \text {, this increase is } \\
\text { slightly lower in Kingston (Jamaica) Is } \\
\text { of }\left(0.7^{\circ} \mathrm{C}\right) .\end{array}$ \\
\hline $\begin{array}{l}\text { Kilbourne } \\
\text { (2008) }\end{array}$ & $\begin{array}{l}\text { 254-year record of coral since } \\
\text { the year } 1751\end{array}$ & Method $\delta^{18} \mathrm{O}$ and $\mathrm{Sr} / \mathrm{Ca}$ & $\begin{array}{c}\text { indicating } 2.1 \pm 0.8^{\circ} \mathrm{C} \text { and } \delta 180 \text { data } \\
\text { indicating } 2.7 \pm 0.5^{\circ} \mathrm{C} .\end{array}$ \\
\hline $\begin{array}{l}\text { Comarazamy } \\
\text { et al (2010) }\end{array}$ & $\begin{array}{l}50 \text { years }(1955-1959 \text { to } 2000- \\
2004)\end{array}$ & $\begin{array}{l}\text { The model chosen for the study is the } \\
\text { Regional Atmospheric Modeling System }\end{array}$ & $\begin{array}{l}\text { air temperature increase between } 2.5 \text { and } \\
\qquad 3^{\circ} \mathrm{C}\end{array}$ \\
\hline Jury (2011) & $1980-2010$ & Observed and projected & $\begin{array}{l}\text { Sea surface height trends were found to } \\
\text { be highest }\left(+.0014 \mathrm{~m} / \mathrm{yr} \text {.) at } 14^{\circ} \text { and } 23^{\circ} \mathrm{N}\right. \\
\text { and lower }(+.0008 \mathrm{~m} / \mathrm{yr} \text {. }) \text { at } 10^{\circ} \text { and } \\
18^{\circ} \mathrm{N} \text {. }\end{array}$ \\
\hline $\begin{array}{l}\text { Murphy } \\
(2011)\end{array}$ & $\begin{array}{l}\text { Air-temperature measurements } \\
\text { were logged automatically at } \\
\text { 5-min intervals, and then } \\
\text { aggregated into hourly averages } \\
\text { for data analysis. }\end{array}$ & $\begin{array}{l}\text { Two methods to capture the variation of } \\
\text { the UHI over space and time: (a) a series } \\
\text { of fixed-station temperature sensors and } \\
\text { (b) a series of mobile measurements from } \\
\text { a vehicle-mounted temperature sensor }\end{array}$ & $\begin{array}{l}\text { The maximum UHI value for } \\
\text { northeastern was calculated as } 4.7^{\circ} \mathrm{C} \\
\text { between the urban and forest sites and } \\
3.9^{\circ} \mathrm{C} \text { between the urban and an open, } \\
\text { rural site. }\end{array}$ \\
\hline $\begin{array}{l}\text { Van } \\
\text { Beusekom et } \\
\text { al (2014) }\end{array}$ & 100 years & Global Climate Models (GCMs) & $\begin{array}{l}\text { an increasing trend for temperature of } \\
0.01^{\circ} \mathrm{C} / \mathrm{yr} \text {. to }+0.03^{\circ} \mathrm{C} / \mathrm{yr} .\left(+1^{\circ} \text { to } 3^{\circ} \mathrm{C} \text { in }\right. \\
100 \text { years }) .\end{array}$ \\
\hline
\end{tabular}

Since the 1990's, Puerto Rico has been affected by many climatic phenomena, including two extensive periods of drought, the first of which began in February 1994 and lasted until September 1996, affecting the entire island. The second episode of drought began in mid-2013 and lasted until November 2015, in this case affecting the eastern third of the island, causing great economic losses and a great social impact (Drought report, 2016).

The increase in temperature on the island is expected to have several adverse effects. (Burrowes, 2004) reported impacts on the population of amphibians (coquies) due to increased temperatures. In marine turtles, sex is determined by temperature in the middle third of incubation, with female offspring produced at higher temperatures and males at lower temperatures, and a thermal tolerance range of $23-35{ }^{\circ} \mathrm{C}$. Other research has concluded that nesting habitat loss from the expected sea level rise would have serious consequences for sea turtle 
populations in the Caribbean regions. Sea level rise will also affect foraging grounds, such as seagrass beds, coral reefs, and the open ocean. Species with limited geographic distribution living in mountainous areas (i.e., in Puerto Rico, the Dwarf Coqui and Yellow-Shinned Anole) will be forced to migrate upland to keep pace with the increased ambient temperature (Ackerman, 1997).

The current evidence presented by (Hernández-Pacheco et al., 2011), among others, also indicates an increase in mortality and bleaching of corals, observed since 2005 , where approximately $70 \%$ of the northeastern corals of Puerto Rico. This has caused great economic losses to the fishing and tourism sector. Other researchers report for 2013-14 an increase in the number of forest fires, this increase is aided by favorable climatic conditions for the occurrence and propagation of these phenomena (Méndez-Tejeda et al., 2016).

\section{Material and Methods}

\subsection{Study Area}

Puerto Rico is located in the center of the Caribbean (between latitudes $18^{\circ} 31^{\prime}$ and $17^{\circ} 55^{\prime} \mathrm{N}$ and longitudes $65^{\circ}$ $37^{\prime}$ and $67^{\circ} 17^{\prime} \mathrm{W}$, between the Atlantic Ocean and the Caribbean Sea), and includes five smaller nearby islands. Puerto Rico is $180 \mathrm{~km}$ long and $65 \mathrm{~km}$ wide and encompasses a total land area of 11,700 km² (fig.1). Precipitation is primarily effected by troughs embedded in easterly waves during the summer months and in cold fronts during winter months. The lowest amount of precipitation in Puerto Rico occurs from December to March. The Caribbean climate depends on several factors, such as the so-called Caribbean Regulators Climate Centers (CRCCs) (Méndez-Tejeda et al., 2016) the North Atlantic Oscillation (NAO), the El Niño Southern Oscillation (ENSO), the trade winds, and the Warm Water Pool North Atlantic, Multidecadal Oscillation, as well as the behavior of the Azores anticyclone. The presence of ENSO, specifically in the 3.4 phase, is associated with drought in the Central Caribbean (Cuba, Hispaniola, Puerto Rico, and Jamaica) and an increase in the intensity of hurricanes in the region (Chen \& Taylor, 2002).

Table 2. Selected stations included in the study, period covered, total day data series, latitude, longitude elevation

\begin{tabular}{cccccc}
\hline Station & Period & \% data & Lat $(\boldsymbol{N})$ & Long. $(\boldsymbol{W})$ & Elevation $(\boldsymbol{m})$ \\
\hline Aguada & $1950-2014$ & 95 & $18^{\circ} 23^{\prime}$ & $67^{\circ} 09^{\prime}$ & 12 \\
Aibonito & $1950-2014$ & 90 & $18^{\circ} 13^{\prime}$ & $66^{\circ} 26^{\prime}$ & 710 \\
Ceiba & $1950-2014$ & 94 & $18^{\circ} 26^{\prime}$ & $65^{\circ} 64^{\prime}$ & 10 \\
Corozal & $1950-2011$ & 92 & $18^{\circ} 20^{\prime}$ & $66^{\circ} 22^{\prime}$ & 198 \\
Guayama & $1950-2014$ & 96 & $17^{\circ} 59^{\prime}$ & $66^{\circ} 05^{\prime}$ & 22 \\
Isabela & $1950-2014$ & 97 & $18^{\circ} 28^{\prime}$ & $67^{\circ} 10^{\prime}$ & 128 \\
Juncos & $1950-2012$ & 98 & $18^{\circ} 22^{\prime}$ & $65^{\circ} 92^{\prime}$ & 65 \\
Lajas & $1950-2012$ & 93 & $18^{\circ} 02^{\prime}$ & $67^{\circ} 04^{\prime}$ & 27 \\
Manatí & $1950-2014$ & 95 & $18^{\circ} 26^{\prime}$ & $66^{\circ} 28^{\prime}$ & 76 \\
Mayagüez & $1950-2013$ & 92 & $18^{\circ} 11^{\prime}$ & $67^{\circ} 08^{\prime}$ & $66^{\prime} 32^{\prime}$ \\
Ponce & $1954-2014$ & 91 & $18^{\circ} 02^{\prime}$ & $66^{\circ} 00^{\prime}$ & 21 \\
San Juan & $1956-2014$ & 98 & $18^{\circ} 26^{\prime}$ & $66^{\circ} 41^{\prime}$ & 3 \\
Utuado & $1950-1998$ & 90 & $18^{\circ} 16^{\prime}$ & & 158 \\
\hline
\end{tabular}

\section{Methodology}

This analysis has been divided into two parts:

In the first part: to determine the trend of the average temperature, the series has been used since 1950-2014 (see following equations)

A selection of 13 meteorological stations of Puerto Rico (see table 1 and fig. 2) was made meeting the following conditions:

- The stations should cover the entire geography of the island and its different climatic zones.

- The data should be validated by NOAA's National Climatic Data Center (NCDC).

- The stations must have less than $10 \%$ missing data.

- Warm days must have temperatures $>32^{\circ} \mathrm{C}$.

- The days should be considered cold if temperatures are $<15^{\circ} \mathrm{C}$. 
Part I

Daily maximum and minimum surface air temperature data were taken from 13 meteorological stations across Puerto Rico, in general, for the period between 1950 - 2014. The station locations are Shown in Figure 2; The numbers indicating the stations and their names and locations are shown in Table 2. The National Data Climate Center-NOAA. After meeting the established criteria, the daily minimum and maximum temperatures are taken and the average daily temperatures are obtained for the complete series. $(\mathrm{Qu}, 2014)$

$$
\bar{T} \min =\frac{1}{n} \sum_{i=1}^{n} \operatorname{Timin}
$$

$\bar{T}$ min Average minimum temperature

Timin Minimum daily temperature

$$
\bar{T} \max =\frac{1}{n} \sum_{i=1}^{n} \operatorname{Timax}
$$

$\bar{T} \max$ Average minimum temperature

Timax Minimum daily temperature

$$
\bar{T} a v=\frac{1}{n} \sum_{i=1}^{n}[\bar{T} \max -\bar{T} \max ]
$$

$\bar{T} a v$ Average temperature

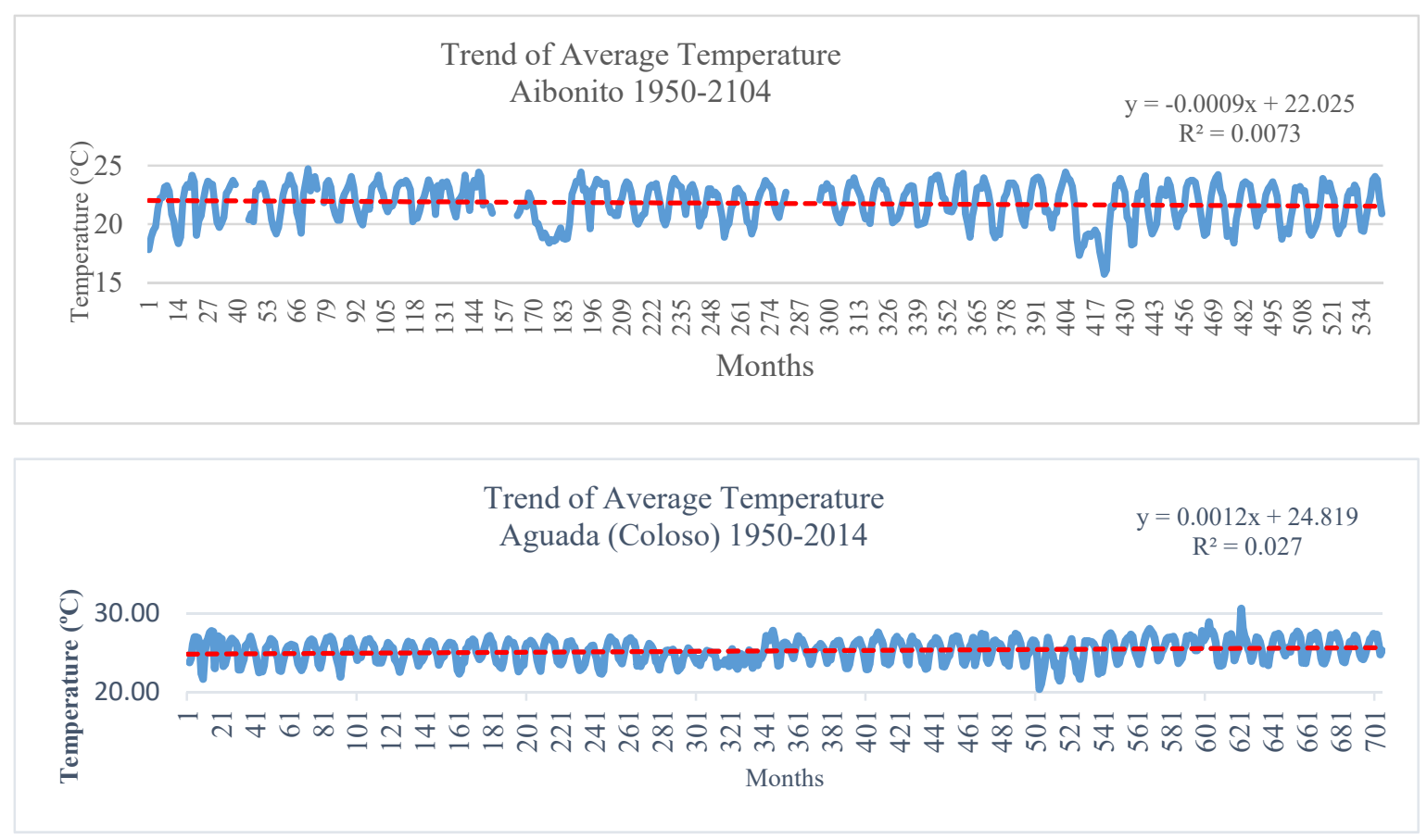



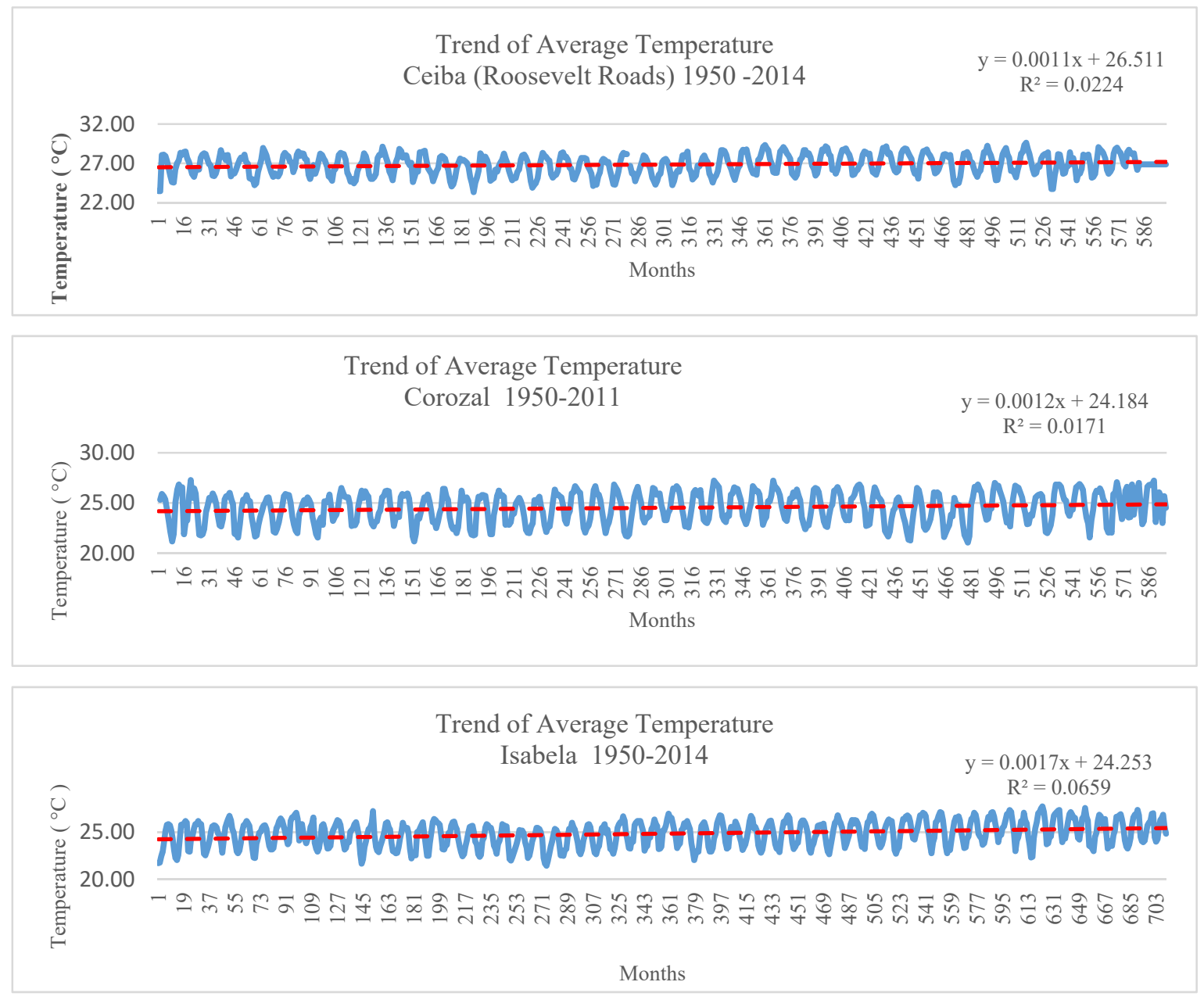

\begin{tabular}{|c|c|}
\hline \multirow{4}{*}{ 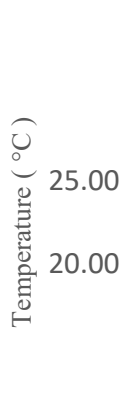 } & $\begin{array}{l}\text { Trend of Average Temperature } \\
\text { Juncos 1950-2012 }\end{array}$ \\
\hline & 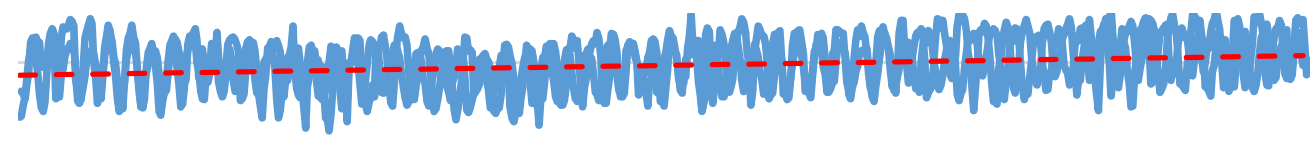 \\
\hline & 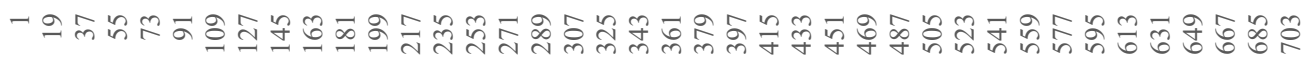 \\
\hline & Months \\
\hline \multirow{4}{*}{ 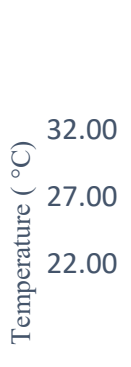 } & Trend of Average Temperature \\
\hline & $\begin{array}{l}\mathrm{y}=0.0022 \mathrm{x}+26.991 \\
\mathrm{R}^{2}=0.1082\end{array}$ \\
\hline & 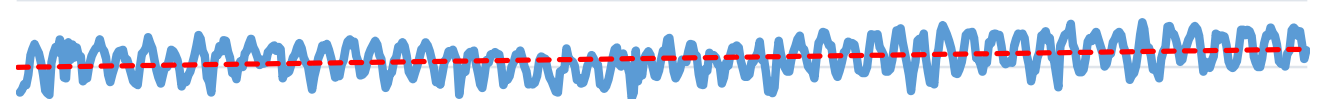 \\
\hline & 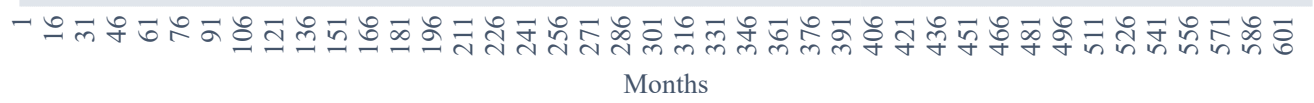 \\
\hline
\end{tabular}




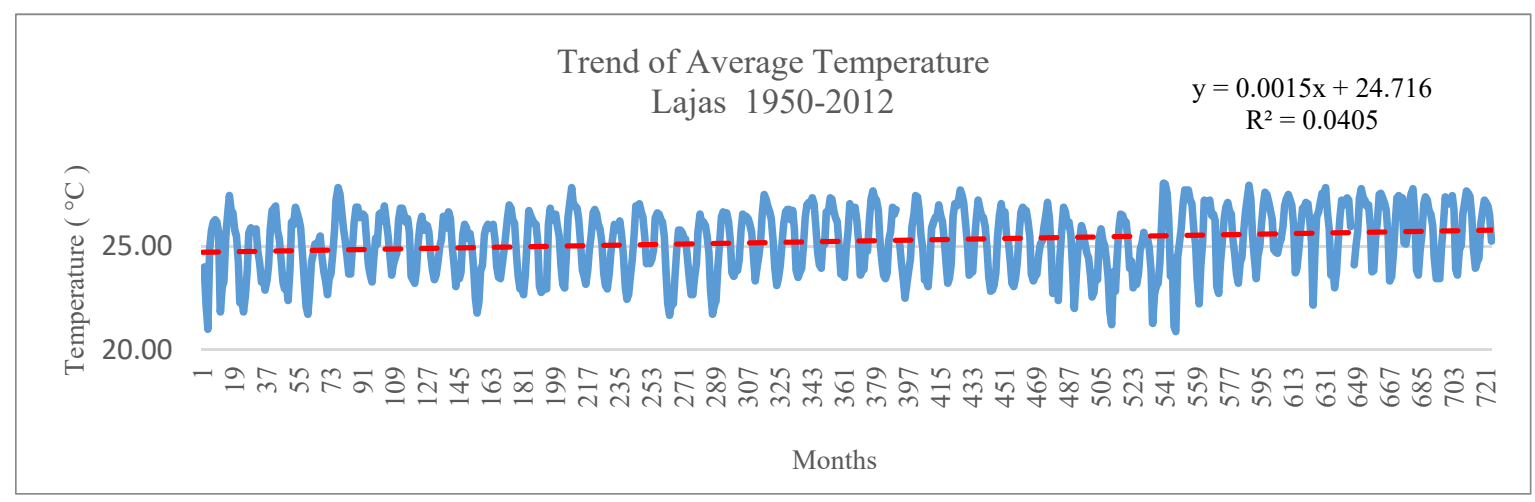

\begin{tabular}{|c|c|}
\hline \multirow{3}{*}{ 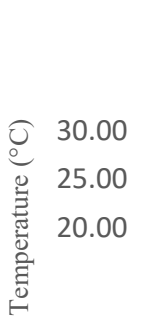 } & $\begin{array}{c}\text { Trend of Average Temperature } \\
\text { Manatí 1950-2014 }\end{array}$ \\
\hline & 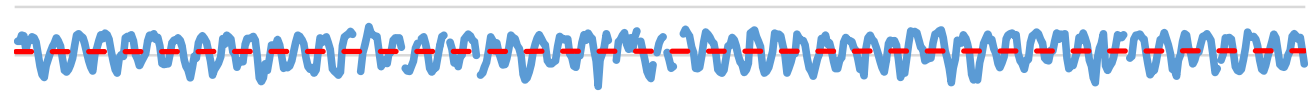 \\
\hline & 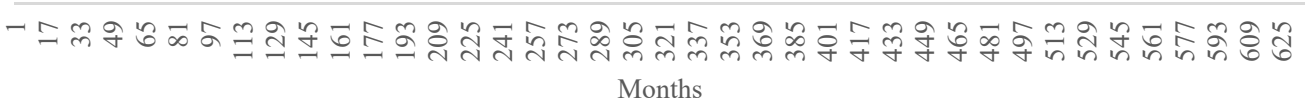 \\
\hline
\end{tabular}

\begin{tabular}{|c|c|}
\hline \multirow{3}{*}{ 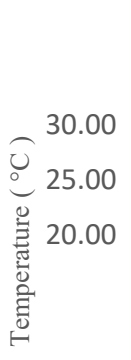 } & $\begin{array}{l}\text { Trend of Average Temperature } \\
\text { Mayaguez 1950-2013 }\end{array}$ \\
\hline & 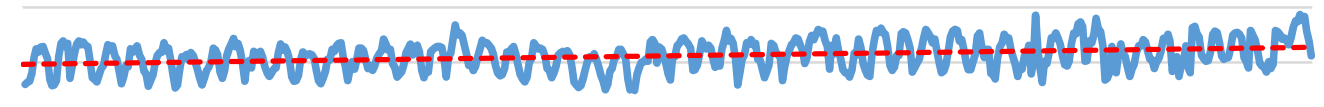 \\
\hline & 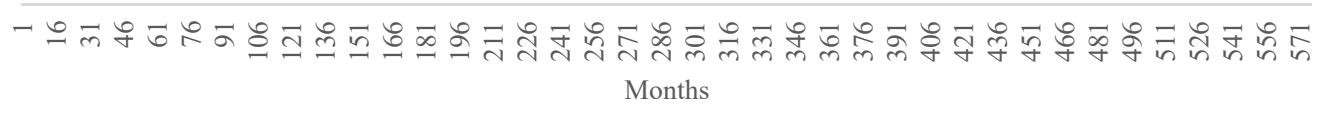 \\
\hline \multirow{3}{*}{ 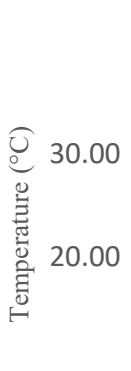 } & $\begin{array}{l}\text { Trend of Average Temperature } \\
\text { Ponce 1954-2014 }\end{array}$ \\
\hline & 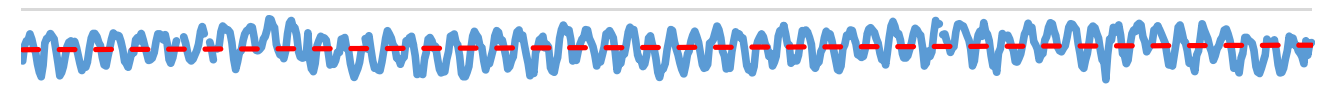 \\
\hline & 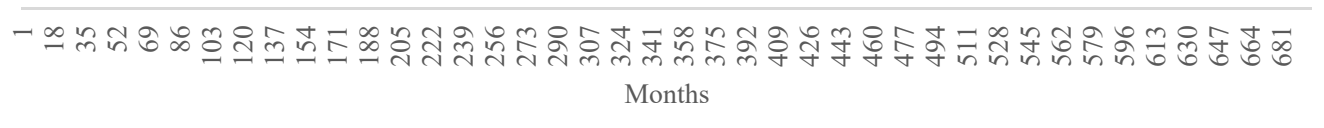 \\
\hline \multirow{3}{*}{ 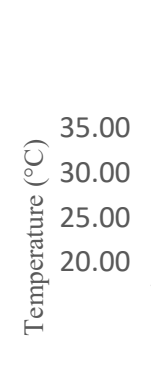 } & $\begin{array}{l}\text { Trend of Average Temperature } \\
\quad \text { San Juan 1956-2014 }\end{array}$ \\
\hline & 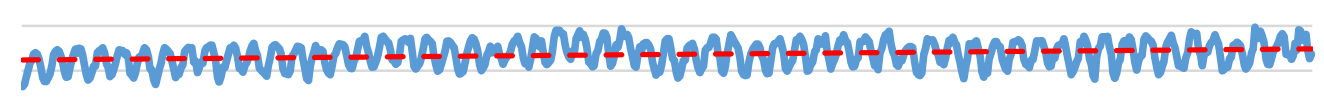 \\
\hline & 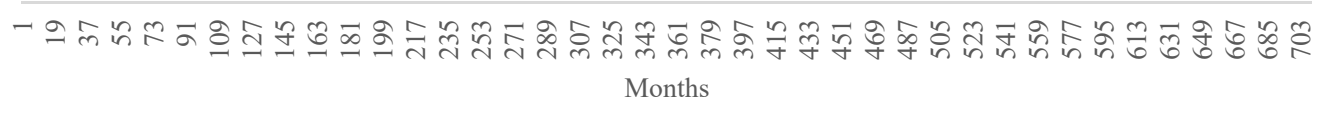 \\
\hline
\end{tabular}


Trend of Average Temperature

Utuado 1950-1998

$y=-0.0011 x+24.39$

$\mathrm{R}^{2}=0.0074$

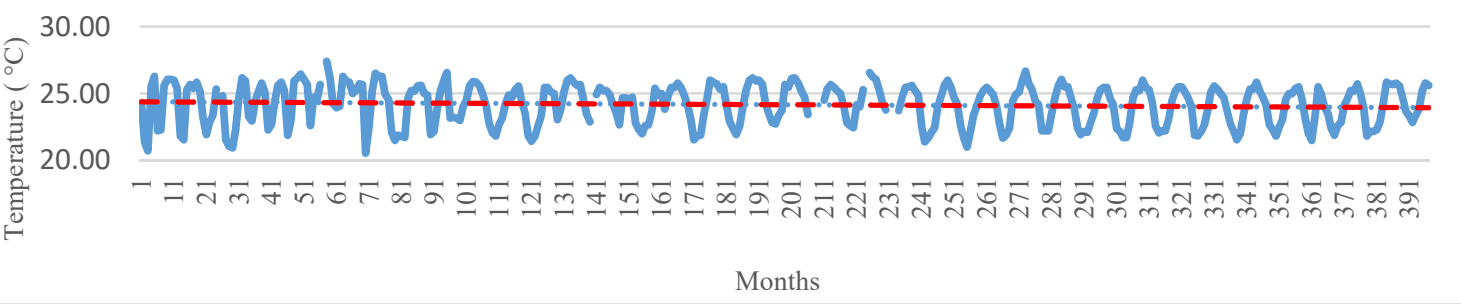

Figure 1. Shows the behavior of the average temperature in the period analyzed for the thirteen (13) meteorological stations

\section{Part II}

In the Second part, the series from 1950 to 2009 was used to determine the relationship between hot and cold days in the seven decades analyzed, with the conditions set out below. The meteorological stations are distributed on all the island (Figure 2).

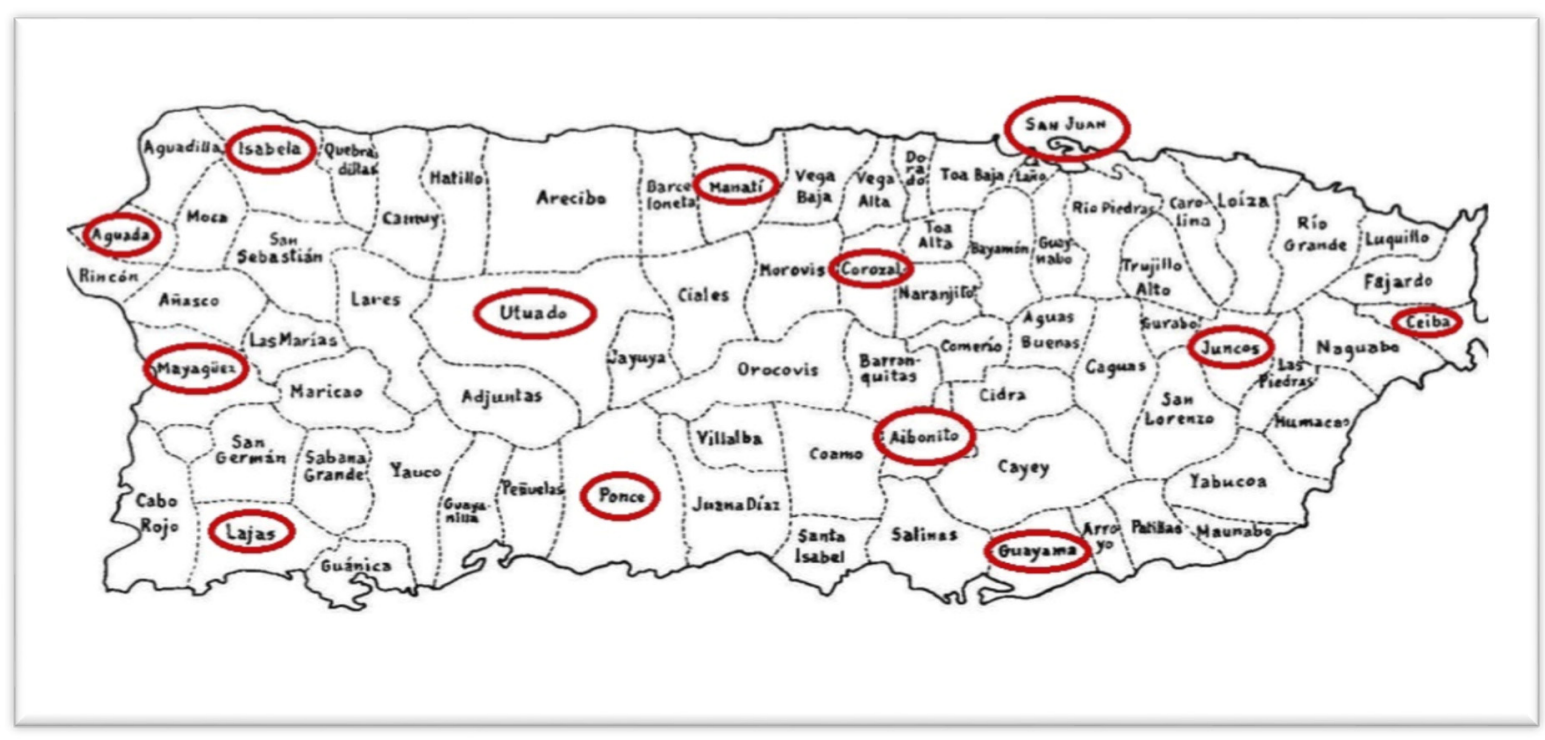

Figure 2. shows the location of the meteorological stations used in the study

During the period analyzed, the stations of Aibonito and Utuado showed a negative tendency in the series of average temperatures, this indicates that the minimum values exceeded the maximums in the series, it should be noted that these stations are located in the center of the island (More mountainous area). In the case of Aibonito has a height of $710 \mathrm{~m}$ above sea level. Stations with a coastal maritime component showed positive slopes (see Figure 1and Table 1) 


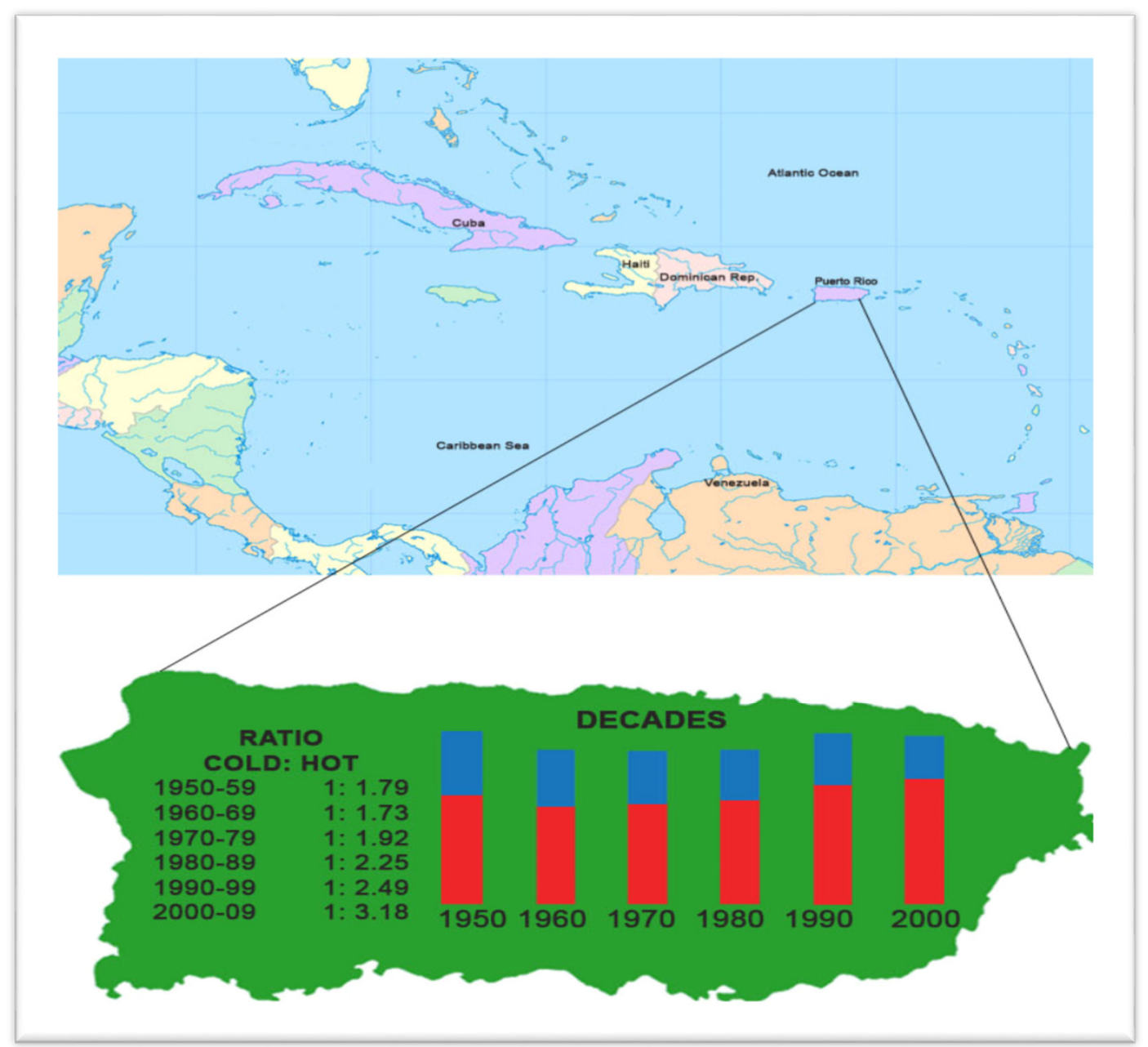

Figure 3. Ratio of record daily highs to record daily lows observed at 13 weather stations across 13 municipalities of Puerto Rico from January 1950 through December 2009. Created by El Centro de Recursos Educaticativos y Produccion (CREP)

\section{Results and Discussion}

In the 1950s, the ratio of warm to cold days was 1.79 hot days for every cold day. An increasing trend ensued, so that, during the 2000s, this ratio increased to 3.18 warm days for each cold day (fig.3). The 1960s decade had a lower hot-to-cold days' ratio, according to analysis of the temperature variability, which indicated increases in the minimum temperature of $0.052{ }^{\circ} \mathrm{C} /$ year and a maximum temperature increase of $0.024{ }^{\circ} \mathrm{C} /$ year.

Rising temperatures have affected Caribbean ecosystems, which enabled an increase in mosquito-borne diseases. Consequently, thousands of people have been infected with diseases such as dengue, chinkungunya, zika and malaria (Hennesse \& Staples, 2016).

Due to the geographic location of the island of Puerto Rico, whose tropical climate (Caribbean region) with high levels of relative humidity, which contributes to a greater heat sensation (heat index). The number of days with temperatures over $32{ }^{\circ} \mathrm{C}$ is three times more than the number of days with temperatures below $15{ }^{\circ} \mathrm{C}$, With the exception of Aibonito which has a height of $710 \mathrm{~m}$ above sea level.

The average temperature of the number of days with temperatures over $32{ }^{\circ} \mathrm{C}$ is $35^{\circ} \mathrm{C}$. While the average temperature of the quantity with temperatures below $15{ }^{\circ} \mathrm{C}$ is $14{ }^{\circ} \mathrm{C}$. This is explained by the weather conditions of the Caribbean region. The seven decades analyzed, only the decade of 1960 shows a decrease in the number of hot days versus the number of cold days, this behavior is in agreement with the findings of (Mehl et al., 2009) 


\section{Conclusion}

- The number of days with temperatures above $32{ }^{\circ} \mathrm{C}$, versus the number of days in which the temperature is below $15{ }^{\circ} \mathrm{C}$, increased by $46 \%$ in the period from $1950-2009$.

- The variability in the minimum temperature is more than twice that of the maximum temperature.

- The average temperature on the island has increased by about $2.24^{\circ} \mathrm{C}$ over the period from $1950-2014$.

- The increase minimum temperature of $0.048{ }^{\circ} \mathrm{C} /$ year and a maximum temperature increase of $0.022^{\circ} \mathrm{C} /$ year in the analyzed period.

- The ratio per decade between cold days and warm days from 1950 to 2000 increases from 1:79 to 1: 3.18.

- The main factor contributing to the increase in temperature in the island of Puerto Rico is the marine component of both the Atlantic Ocean and the Caribbean Sea. Another two important factors are the deforestation process and the enormous urban growth. (Velázquez-Lozada, 2006).

- Our results coincide with those reported by (Lau \& Kin, 2009) and (Prospero \& Lamb, 2003), the results show that the estimated anomalous cooling pattern of the Atlantic during June 2006 compared to June 2005 due to attenuation of surface solar radiation by Saharan dust is remarkably similar to observations, representing approximately $30-40 \%$ of the observed change in sea surface temperature.

\section{Acknowledgements}

The author wishes to thank Josue J. Ulloa for his contribution in the data analysis, as well as his presentation at the Junior Technical Meeting at the University of Puerto Rico in Carolina, and to the ALAAS project for providing the funds for this research. In addition, Daniel Meléndez from NOAA for his important comments and suggestions.

\section{Competing interests}

Author have declared that no competing interests exist.

\section{References}

Ackerman, R. A. (1997). The nest environmental and the embryonic development of sea turtles. In P, L. Lutz, \& J. A. Musik (Eds.), The Biology of Sea Turtles (pp. 83-106). Boca Raton, CRC Press.

Burrowes, P. A., Joglar, R. L., \& Green, D. E. (2004). Potential causes for amphibian declines in Puerto Rico. Herpetologica, 60, 141-154

Chen, A. A., \& Taylor, M. (2002). Investigating the link between early season Caribbean rainfall and the El Niño year. Int J Climatol, 22, 87-106.

Climate Change Council. (2017). Puerto Rico's State of the Climate 2010-2013. Social-Ecological Vulnerabilities in a Changing Climate. Retrieved from http://pr-ccc.org/publications/other-publications/

Comarazamy, D. E., González, J. E., Luvall, J. C., Rickman, D. L., \& Mulero, P. J. (2010), A land-atmospheric interaction study in the coastal tropical city of San Juan, Puerto Rico. Earth Interact., 14, 1-24, http://dx.doi.org/10.1175/2010EI309.1

Duchon, C. E. (1986). Temperature trends at San Juan, Puerto Rico. Bulletin of the American Meteorological Society, 67(11), 1370-1377.

Foltz, G. R., \& McPhaden, M. J. (2008). Impact of Saharan dust on tropical North Atlantic SST. Journal of Climate, 21(19), 5048-5060. http://dx.doi.org/10.1175/2008JCLI2232.1

Gamble, D. W. (2009). Caribbean vulnerability: development of an appropriate climatic framework. In D. F. M. McGregor, D. Dodman, \& D. Barker (Eds.), Global Change and Caribbean Vulnerability: Environment, Economy and Society at Risk (pp. 22-46)? UWI Press, Kingston.

Hall, T. C., Sealy, A. M., Stephenson, T. S., Kusunoki, S., Taylor, M. A., Chen, A. A., \& Kitoh, A. (2013). Future climate of the Caribbean from a super-high-resolution atmospheric general circulation model. Theoretical and applied climatology, 113(1-2), 271-287.

Hennessey, M., Fischer, M., \& Staples, J. E. (2016). Zika virus spreads to new areas-region of the Americas, May 2015-January 2016. American Journal of Transplantation, 16(3), 1031-1034. Retrieved from http://onlinelibrary.wiley.com/doi/10.1111/ajt.13743/epdf

Hernández-Pacheco, R., Hernández-Delgado, E. A., \& Sabat, A. M. (2011). Demographics of bleaching in a major Caribbean reef-building coral: Montastraea annularis. Ecosphere, 2(1), 1-13. Retrieved from https://www.ipcc.ch/pdf/assessment report/ar5/wg1/WG1AR5_Frontmatter_FINAL.pdf 
Intergovernmental Panel on Climate Change. (2014). Climate Change 2014: Impacts, Adaptation and vulnerability. Retrieved from https:/www.ipcc.ch/pdf/assessment-report/ar5/wg2/WGIIAR5-Integration Brochure_FINAL.pdf

Intergovernmental Panel on Climate Change. (2014). Climate Change 2014: Impacts, Adaptation and vulnerability. Retrieved from https:/www.environment.gov.za/sites/default/files/docs/impactsadaptation vulnerability_wg2.pdf

Intergovernmental Panel on Climate Change. (2014). Climate Change 2014-Impacts, Adaptation and Vulnerability: Regional Aspects. Cambridge University Press.

Jury, M. R. (2011). Long-term variability and trends in the Caribbean Sea. International Journal of Oceanography, 2011. https://doi.org/10.1155/2011/465810

Kilbourne, K. H., Quinn, T. M., Webb, R., Guilderson, T., Nyberg, J., \& Winter, A. (2008). Paleoclimate proxy perspective on Caribbean climate since the year 1751: Evidence of cooler temperatures and multidecadal variability. Paleoceanography, 23(3). https://doi.org/10.1029/2008PA001598.

Lau, K. M., \& Kim, K. M. (2007). Cooling of the Atlantic by Saharan dust. Geophysical Research Letters, 34. L23811. https://doi.org/10.1029/2007GL031538

Meehl, G. A., Tebaldi, C., Walton, G., Easterling, D., \& McDaniel, L. (2009). Relative increase of record high maximum temperatures compared to record low minimum temperatures in the US. Geophysical Research Letters, 36(23). https://doi.org/10.1029/2009GL04073

Méndez-Lázaro, P. A., Pérez-Cardona, C. M., Rodríguez, E., Martínez, O., Taboas, M., Bocanegra, A., \& Méndez-Tejeda, R. (2016). Climate change, heat, and mortality in the tropical urban area of San Juan, Puerto Rico. International Journal of Biometeorology, 1-9. https://doi.org/10.1007/s00484-016-1291-z

Méndez-Lázaro, P., Martínez-Sánchez, O., Méndez-Tejeda, R., Rodríguez, E., Morales, E., \& Schmitt-Cortijo, N. (2015). Extreme heat events in San Juan Puerto Rico: Trends and variability of unusual hot weather and its possible effects on ecology and society. Journal of Climatology \& Weather Forecasting, 1-7. https://doi.org/10.4172/2332-2594.1000135

Méndez-Tejeda, R., Rosado, G., Rivas, D. V., Montilla, T., Hernández, S., Ortiz, A., \& Santos, F. (2016). Climate Variability and Its Effects on the Increased Level of Lake Enriquillo in the Dominican Republic, 2000-2013. Applied Ecology and Environmental Sciences, 4(1), 26-36. https://doi.org/10.12691/aees-4-1-4

Murphy, D. J., Hall, M. H., Hall, C. A., Heisler, G. M., Stehman, S. V., \& Anselmi-Molina, C. (2011). The relationship between land cover and the urban heat island in northeastern Puerto Rico. International Journal of Climatology, 31(8), 1222-1239.

Palanisamy, H., Becker, M., Meyssignac, B., Henry, O., \& Cazenave, A. (2012). Regional sea level change and variability in the Caribbean sea since 1950. Journal of Geodetic Science, 2(2), 125-133. https://doi.org/10.2478/v10156-011-0029-4

Peterson, T. C., Taylor, M. A., Demeritte, R., Duncombe, D. L., Burton, S., Thompson, F., ... \& Klein Tank, A. (2002). Recent changes in climate extremes in the Caribbean region. Journal of Geophysical Research: Atmospheres, 107(D21). https://doi.org/10.1029/2002JD002251PR-CCC.org

Prospero, J. M., \& Lamb, P. J. (2003). African droughts and dust transport to the Caribbean: Climate change implications. Science, 302(5647), 1024-1027.

Qu, M., Wan, J., \& Hao, X. (2014). Analysis of diurnal air temperature range change in the continental United States. Weather and Climate Extremes, 4, 86-95. https://doi.org/10.1016/j.wace.2014.05.002.

Rafael, M. T., María, S. C., Sergio, O. M., \& Oscar, C. V. (2015). Environmental and Economic Impact of Forest Fires in Puerto Rico 2013-2014. Open Journal of Forestry, 5(04), 353. http://dx.doi.org/10.4236/ ojf.2015.54030

Rhiney, K. (2015). Geographies of Caribbean vulnerability in a changing climate: Issues and trends. Geography Compass, 9(3), 97-114. https://doi.org/10.1111/gec3.12199.

Singh, B. (1997). Climate Changes in the greater and Southern Caribbean. International Journal of Climatology, 17, 1093-1114. 
Stephenson, T. S., Vincent, L. A., Allen, T., Van Meerbeeck, C. J., McLean, N., Peterson, T. C., ... \& Boekhoudt, J. R. (2014). Changes in extreme temperature and precipitation in the Caribbean region, 1961-2010. International Journal of Climatology, 34(9), 2957-2971. https://doi.org/10.1002/joc.3889

Strelich, L. (2015). Sea surface temperatures on the rise in the Caribbean. Eos, 96. https://oi.org/10.1029/ 2015EO039535

Taylor, M. A., Stephenson, T. S., Chen, A. A., \& Stephenson, K. A. (2012). Climate change and the Caribbean: Review and response. Caribbean Studies, 40(2), 169-200.

United States Drought Monitor. (2016). Drought report. Retrieved from http://droughtmonitor.unl.edu/ Home/StateDroughtMonitor.aspx?PR

Van Beusekom, A. E., González, G., \& Rivera, M. M. (2015). Short-term precipitation and temperature trends along an elevation gradient in Northeastern Puerto Rico. Earth Interactions, 19(3), 1-33. https://doi.org/10.1175/EI-D-14-0023.1

Velazquez-Lozada, A., Gonzalez, J. E., \& Winter, A. (2006). Urban heat island effect analysis for San Juan, Puerto Rico. Atmospheric Environment, 40(9), 1731-1741. http://doi.org/10.1016/j.atmosenv.2005.09.074

Wang, C., Dong, S., Evan, A. T., Foltz, G. R., \& Lee, S. K. (2012). Multidecadal covariability of North Atlantic sea surface temperature, African dust, Sahel rainfall, and Atlantic hurricanes. Journal of Climate, 25(15), 5404-5415. http://dx.doi.org/10.1175/JCLI-D-11-00413.1

\section{Copyrights}

Copyright for this article is retained by the author(s), with first publication rights granted to the journal.

This is an open-access article distributed under the terms and conditions of the Creative Commons Attribution license (http://creativecommons.org/licenses/by/4.0/). 